\title{
Alternative fixation system for implant-retained overdenture: case report
}

\author{
Sistema alternativo de fixação para overdenture \\ implanto-retida: relato de caso
}

\author{
Mariana Lima da Costa VALENTE ${ }^{1}$ iD 0000-0002-8144-0467 \\ Denise Tornavoi de CASTRO $^{1}$ iD 0000-0001-8180-7858 \\ Frank Lucarini BUENO ${ }^{1}$ iD 0000-0001-6622-4865 \\ Ana Beatriz Vilela TEIXEIRA ${ }^{1}$ (D) 0000-0002-0679-0301 \\ Geyson Galo da SILVA ${ }^{1}$ 0000-0003-3454-0446 \\ Andréa Cândido dos REIS ${ }^{1}$ iD 0000-0002-2307-1720
}

\section{ABSTRACT}

The aim of this case report was to describe a prosthetic rehabilitation associated with an alternative model of polymer capsule for fixation system of implant-retained overdentures. Patient sought treatment at the clinic of School of Dentistry of Ribeirão Preto, due to lack of retention of their conventional total superior prostheses and inferior overdenture. The initial complaint was clinically confirmed by altered intermaxillary relationships and severe reabsorption of the maxillary crest. In order to restore the function and improve its quality of life, it was proposed a prosthetic solution including implant fixed prosthesis to maxilla and a mandibular overdenture, with ball-type attachments associated with an alternative model of polymer capsule. This treatment was proposed in order to reestablish the intermaxillary relationships and adequate occlusion, maintain retention and stability of the prosthesis. At the end of treatment and during a one-year follow-up of the case, the patient reported satisfaction and significant improvement in quality of life.

Indexing terms: Dental implantation. Polymers. Quality of life.

\section{RESUMO}

O objetivo deste relato de caso foi descrever uma reabilitação protética associada a um modelo alternativo de cápsula polimérica para sistema de fixação de overdentures implantado-retidas. Paciente procurou tratamento na clínica da Faculdade de Odontologia de Ribeirão Preto, devido falta de retenção de suas próteses totais superiores convencionais e overdenture inferior. A queixa inicial foi clinicamente confirmada por relações intermaxilares alteradas e reabsorção severa da crista maxilar. Para restaurar a função e melhorar sua qualidade de vida, propôs-se como solução protética, a confecção de prótese fixa sobre implantes para a maxila e

\footnotetext{
$\operatorname{rrv}$
}

1 Universidade de São Paulo, Faculdade de Odontologia de Ribeirão Preto, Departamento de Materiais Dentários e Prótese. Av. do Café, s/n., 14040-904, Ribeirão Preto, SP, Brasil. Correspondência para / Correspondence to: AC REIS. E-mail: <andreare73@yahoo.com.br>.

$\boldsymbol{v} \mathbf{v}$

How to cite this article

Valente MLC, Castro DT, Bueno FL, Teixeira ABV, Silva GG, Reis AC. Alternative fixation system for implant-retained overdenture: case report. RGO, Rev Gaúch Odontol. 2019;67:e20190051. http://dx.doi.org/10.1590/1981-86372019000513649 
overdenture mandibular, com acessórios tipo bola associados a um modelo alternativo de cápsula polimérica. Esse tratamento foi proposto a fim de restabelecer as relações intermaxilares e a oclusão adequada, manter a retenção e a estabilidade da prótese. Ao final do tratamento e durante o acompanhamento de um ano do caso, o paciente relatou satisfação e melhora significativa na qualidade de vida.

Termos de indexação: Implantação dentária. Polímeros. Qualidade de vida.

\section{INTRODUCTION}

The success of oral rehabilitation with implants requires planning the case with consideration of the stomatognathic system as a whole, in order to promote favorable biomechanics, masticatory efficiency, implant longevity, and aesthetics. Although fixed prostheses are the models of choice for fully edentulous cases, patients with bone and systemic conditions are not always good candidates for this type of treatment. In these cases, implant-retained overdentures are an effective alternative, as they significantly improve patient function and satisfaction [1-3].

For overdentures, retention and stability characteristics are provided by the implants through the fixation system, classified as splinted, such as bar-type, and non-splinted, such as era®, magnetic and O-ring [4]. The shape of the dental arch, space inter-arches, implant placement, ease of adjustment, manual dexterity, and patient agreement will determine the most appropriate system choice [5]. Ball attachments are easy to insert, remove, hygiene, and are generally cost-effective [6-8]. The main disadvantage is the need for periodic O-ring replacements [9].

The constant loss of overdenture retention due to O-ring wear is caused by a number of factors, including inadequate positioning of the implants, unfavorable intermaxillary relationships, and fracture of fixation components, all of which result in greater or lesser degrees of wear for these components [9-12]. In an attempt to solve the problems related to fixing the components available in the dental market, the development of products, using materials, equipment, and techniques that overcome the clinical difficulties associated with oral rehabilitation, could lead to substantial improvement in health conditions and quality of life, particularly among patients that depend on this treatment modality [13].

Differences in wear on component surfaces, and in the resistance to insertion and removal of the prostheses after repetitive cycles, may also be associated with the use of various materials in the fixation system, such as metalmetal or metal-polymer [8]. The development of capsules with variable retention capacity, exploiting the full extent of the mechanical properties of each material, represents a viable solution.

Polytetrafluoroethylene (Teflon $®$ ) is a polymeric material that is not commonly used in dentistry, generally applied to build materials, household and computer equipment. In Dentistry is applied to guide tissue regeneration, matrices, instrument coating and filling of the access channel to over-implant prosthesis screws [14]. However, as overdenture retention capsule, its application is inedited. The Teflon $®$ is a physiologically inert material, acids and solvents resistant, such as hygiene chemical solutions, presents anti-adherent properties and low coefficient of static and kinetic friction, that allows the reduction of cell adhesion and of the microorganisms [1416]. This material was evaluated in vitro as for retention force and deformation, presenting satisfactory results as fixation system for overdenture [16].

Prosthesis retention may be one of the most important requirements to be achieved during treatment of the edentulous patient, due to its substantial effect on function and quality of life. Thus, this case report describes the replacement of a conventional maxillary total prostheses by a fixed prosthesis, and the creation of a new mandibular overdenture using a Teflon ${ }^{\circledR}$ polymer capsule fixation system (patent BR102016028989) [16], aiming to satisfy the patient regarding improvement in retention and stability of both prostheses.

\section{CASE REPORT}

A 84 years old male patient with good systemic health conditions, searched theSchool of Dentistry of Ribeirão Preto, University of São Paulo with complaint lack of retention and stability of maxillary total prosthesis and mandibular overdenture. Clinical and radiographic examinations revealed the presence of two inferior implants in the region of the teeth 33 and 43, with 
severe reabsorption of the maxillary border, as well as an inadequate intermaxillary relation between the prostheses, O-ring wear, and unfavorable aesthetics. We noted no other pertinent features of his medical history.

To manage the patient's complaints, we proposed a plan for installation of four implants in the upper arch in the region of teeth 12, 14, 22 and 24, to support the fixed prosthesis, and simultaneously create a new overdenture with a conventional O-ring system.

After installation of the new prostheses, the patient returned to the clinic complaining of lack of retention of the inferior overdenture. Clinical examination revealed O-ring wear, instability of the prosthesis, and difficulty with insertion. Then was suggested to replace the conventional capsule with O-ring with an alternative model, made of polymeric material, Teflon $^{\circledR}$, with dimensions of $\varnothing 4 \times 3 \mathrm{~mm}$.

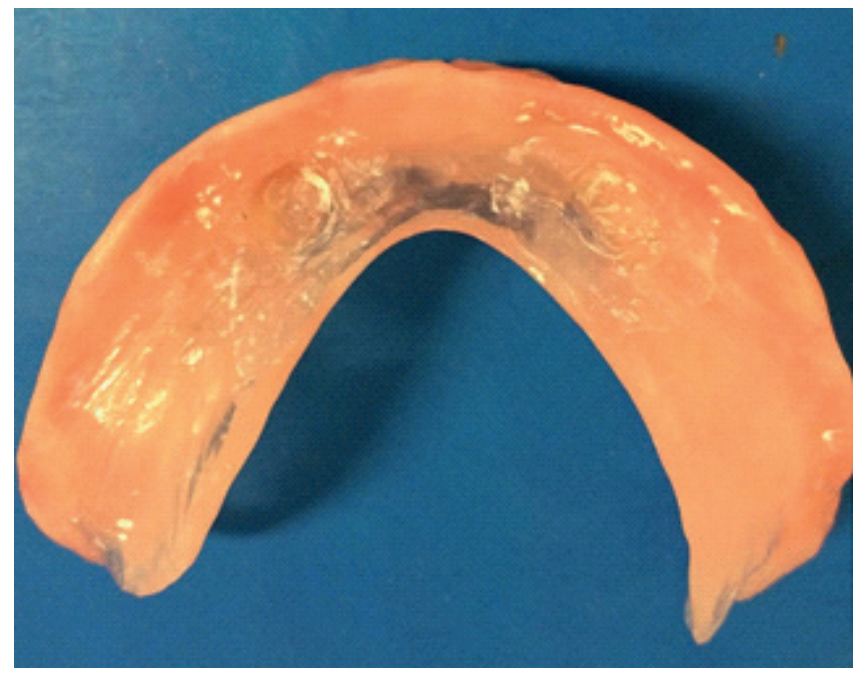

Figure 1. Overdenture prepared for capture of capsules.

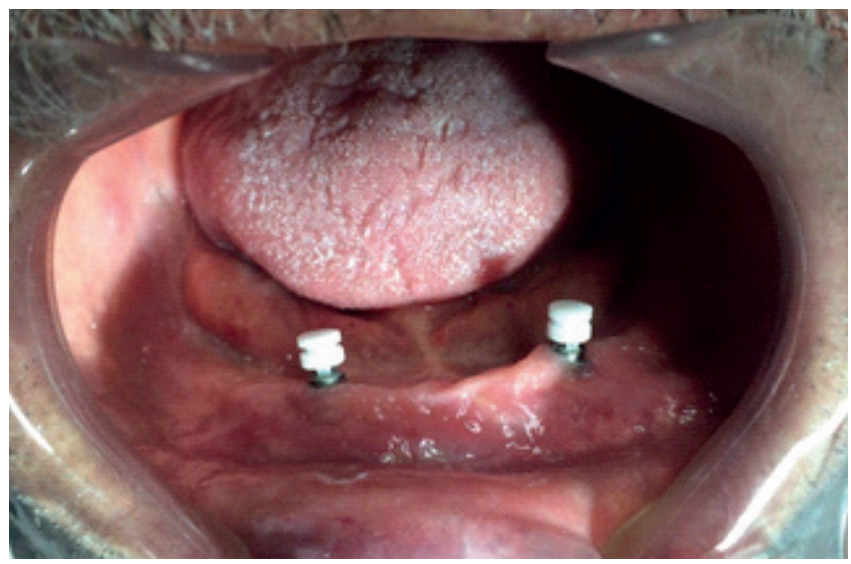

Figure 2. Teflon capsules positioned on the implant ball attachments.
The conventional capsules were removed with a frusto-conical cutter (figure 1 ) and the Teflon ${ }^{\circledR}$ capsules (Fig. 2 and 3) were fixed with autopolymerizable acrylic resin (Clássico, Campo Limpo Paulista, SP, Brazil). After polymerization was performed the finished, polished (Fig. 4), and installed the prostheses (Fig. 5). Soft tissues

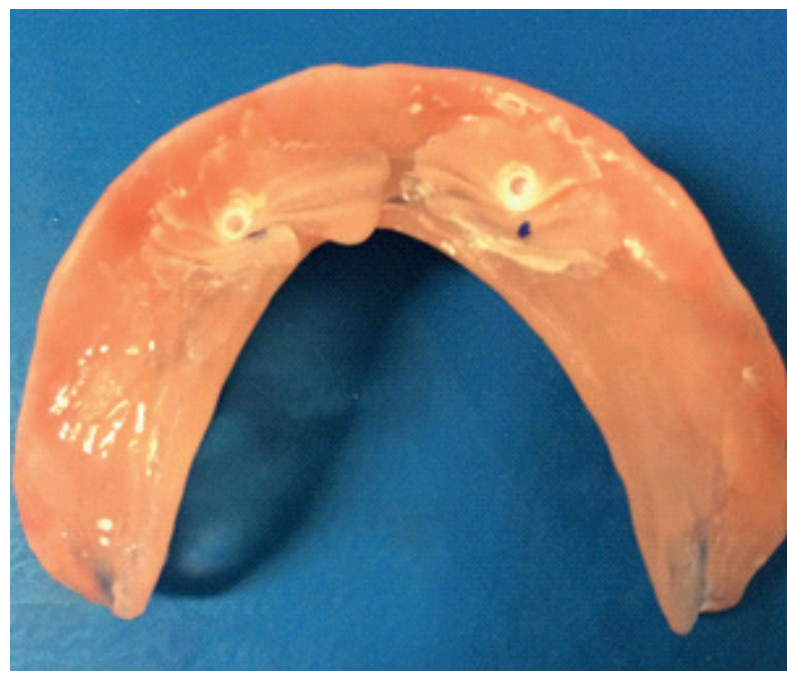

Figure 3. Teflon capsules captured.

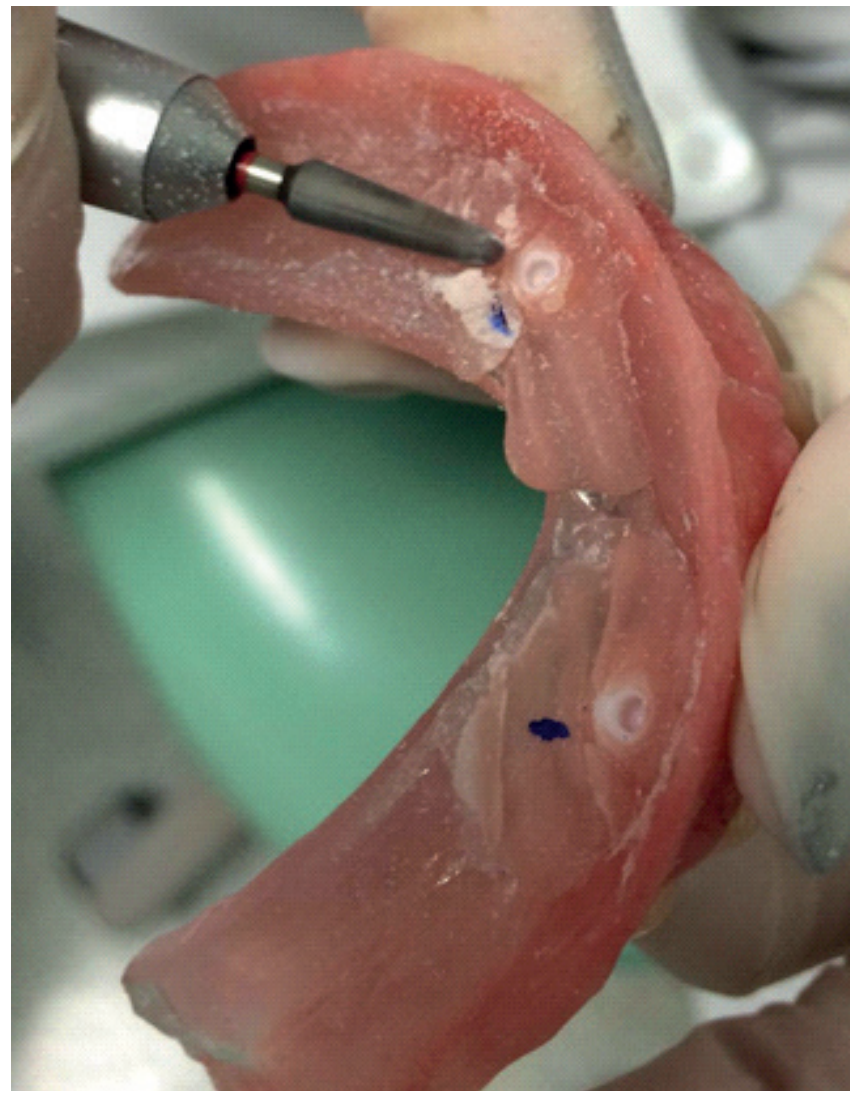

Figure 4. Finishing and polishing after capture of capsules. 
conditions, mandibular overdenture adaptation and retention showed satisfactory results clinically analyzed and reported by the patient during the 6-months follow up.

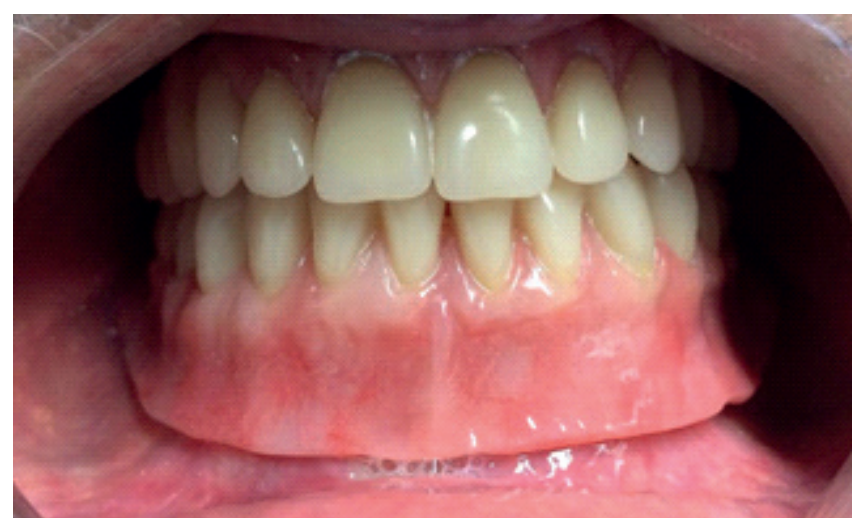

Figure 5. Installed overdenture prostheses.

\section{DISCUSSION}

Conventional total prostheses have long been considered standard treatment for restoring the stomatognathic system of fully edentulous patients. However, the presence of severe bone resorption, especially of the mandible, generates a series of inconveniences, including lack of retention and stability, difficulty masticatory, and speech and psychosocial problems $[4,11,17]$

Among the modalities for implant-supported prostheses, mandibular overdentures have been widely used, since they require a reduced number of implants compared with fixed prostheses, which makes it possible to be indicated in cases of bone resorption, as they are less expensive and are easily hygiene, especially by geriatric patients with limited manual dexterity $[4,17]$.

The most commonly associated prosthetic complication (33\%) with the use of overdentures $[8,12,18]$ is wear of the fixation components, due to functional loads, the insertion/removal path of the prosthesis, implant angulation, or the presence of parafunctional habits7, generating the need for periodic maintenance $[12,19,20]$. Thus, for longevity of restorative treatments, biomechanical principles must be respected in order to guarantee maximum effectiveness of the materials used.

Dental restoration procedures are constantly developing. One reason for this is the more effective use of newer materials with better handling and application properties. As a result, several techniques have been described to assist clinicians in obtaining predictable restorative dental procedures [14,21]. Thus, detailed planning involving medical, surgical and prosthetic knowledge is of great importance in order for new materials and technologies to be effective. In the present case, after diagnosis and planning, a fixed prosthesis for the maxillary arch and a mandibular overdenture replacement were indicated, due to the persistent lack of retention and stability associated with the commercial O-ring component, which was both clinically verified and reported by the patient.

Synthetic biomaterials have significant advantages. Among them are high chemical resistance, which minimizes the degradation caused by the use of hygienic solutions, and low cellular adhesion [15]. Although the use of metallic accessories with the O-ring for overdenture retention is established in the literature, the characteristics of synthetic biomaterials justify its use for the production of prosthetic components.

Considering that the degree of retention and stability of the overdenture is based, among other factors, on the type and design of the attachment, it was decided in this case report by the use of an alternative model for the connection of the inferior overdenture, using a polymeric material, Teflon $®$, in an attempt to provide greater patient satisfaction.

Polytetrafluoroethylene (PTFE) is a physiologically inert polymer widely used in industry and in many medical fields, such as mesh for hernia surgeries and vascular grafts [22-24]. Studies have reported the use of this material in dentistry as a way to reduce bacterial adhesion. This is a desirable property for prosthetic components, as they are directly related to the development of biofilms that provide pathways for colonization and invasion of pathogens into bony tissue $[15,25]$.

The supra or subgingival location of the prosthetic components seems to have a significant influence on the formation of biofilm, so the choice of material in component manufacture must be strategic, to inhibit bacterial colonization. Titanium ( $\mathrm{Ti}$ ) and zirconium oxide ( $\mathrm{ZrO} 2$ ) are the most used in the manufacture of components, however, no antimicrobial coating is known for such surfaces [25].

In clinical experience, a favorable acrylic resin/ Teflon capsule union has been reported. The proposed retention system contributed decisively to the retention 
and stabilization of the overdenture, resulting in patient satisfaction and improved self-esteem.

\section{CONCLUSION}

The retention and stability of overdentures are important factors for the success of the treatment. These can be obtained with the use of polymeric components, as reported in the present study. The fixation system used showed good results at follow-up.

\section{Collaborators}

MLC VALENTE, participated in the design of the study, performed clinical procedures on the patient, drafted and critically reviewed the article. DT CASTRO, performed clinical procedures on the patient, drafted and critically reviewed the article. FL BUENO, performed clinical procedures on the patient, and critically reviewed the article. ABV TEIXEIRA, performed clinical procedures on the patient, drafted and critically reviewed the article. GG SILVA, participated in the design of the study, performed clinical procedures on the patient, drafted and critically reviewed the article. AC REIS, participated in the conception and design of the study, performed clinical procedures on the patient, drafted and critically reviewed the article. All authors read and approved the final version of the manuscript.

\section{Funding Information}

This investigation was supported by FAPESP, grant number 2014/27362-2, São Paulo (SP), Brazil.

\section{REFERENCES}

1. Tomasi C, Idmyr BO, Wennström JL. Patient satisfaction with mini-implant stabilised full dentures. A 1-year prospective study. J Oral Rehabil. 2013;40(7):526-34. http://dx.doi. org/10.1111/ joor. 12053

2. Elsyad MA. Patient satisfaction and prosthetic aspects with mini-implants retained mandibular overdentures. A 5-year prospective study. Clin Oral Implants Res. 2016;27(7):926-33. http://dx.doi.org/10.1111 / clr.12660

3. Assaf A, Daas M, Boittin A, Eid N, Postaire M. Prosthetic maintenance of different mandibular implant overdentures: A systematic review. J Prosthet Dent. 2017;118(2):144-52. http://dx.doi.org/10.1016 / j.prosdent.2016.10.037

4. El-Anwar MI, El-Taftazany EA, Hamed HA, ElHay MAA. Influence of number of implants and attachment type on stress distribution in mandibular implant-retained overdentures: finite element analysis. Open Access Maced J Med Sci. 2017;5(2):244-49. http://dx.doi.org/10.3889 / oamjms. 2017.047

5. Kim SM, Choi JW, Jeon YC, Jeong CM, Yun MJ, Lee $\mathrm{SH}$, et al. Comparison of changes in retentive force of three stud attachments for implant overdentures. J Adv Prosthodont. 2015;7(4):303-11. http://dx.doi.org/10.4047 / jap.2015.7.4.303

6. Fatalla AA, Song K, Cao YG. New mini dental implant attachments versus O-ring attachment after cyclic aging: Analysis of retention strength and gap space. J Huazhong Univ Sci Technolog Med Sci. 2017;37(3):419-24. http://dx.doi. org/10.1007 / s11596-017-1750-8

7. Kobayashi M, Srinivasan M, Ammann P, Perriard J, Ohkubo C, Müller $F$, et al. Effects of in vitro cyclic dislodging on retentive force and removal torque of three overdenture attachment systems. Clin Oral Implants Res. 2014;25(4):426-34. http:// dx.doi.org/10.1111/ clr.12156

8. Shastry T, Anupama NM, Shetty S, Nalinakshamma M. An in vitro comparative study to evaluate the retention of different attachment systems used in implant-retained overdentures. J Indian Prosthodont Soc. 2016;16(2):159-66. http://dx.doi. org/10.4103 / 0972-4052.176520

9. Chaves CA, Souza RF, Cunha TR, Vecchia MP, Ribeiro AB, Bruniera JF, et al. Preliminary In Vitro Study on O-Ring Wear in Mini-Implant-Retained Overdentures. Int J Prosthodont. 2016; 29(4):357-59. http://dx.doi.org/10.11607 / ijp.4677

10. Zarb G, Hobkirk JA, Eckert SE, Jacob RF. Prosthodontic treatments for edentulous patients: complete dentures and implant-supported prostheses. 13th ed. St. Louis: Mosby; 2013.

11. Choi JW, Bae JH, Jeong CM, Huh JB. Retention and wear behaviors of two implant overdenture stud-type attachments at different implant angulations. J Prosthet Dent. 2017; 117(5):628-35. http://dx.doi.org/10.1016 / j.prosdent.2016.09.027

12. ELsyad MA, Elhaddad AA, Khirallah AS. Retentive Properties of O-Ring and Locator Attachments for Implant-Retained Maxillary Overdentures: An In Vitro Study. J Prosthodont. 2018; 27(6):568-76. http://dx.doi.org/10.1111 / jopr.12534

13. Roohi, Bano K, Kuddus M, Zaheer MR, Zia Q, Khan MF, et al. Microbial Enzymatic Degradation of Biodegradable Plastics. Curr Pharm Biotechnol. 2017;18(5):429-40. http://dx.doi. org/10.2174 / 1389201018666170523165742

14. Sattar MM, Patel M, Alani A. Clinical applications of polytetrafluoroethylene (PTFE) tape in restorative dentistry. Br Dent J. 2017; 222(3):151-58. http://dx.doi.org/10.1038/ sj.bdj.2017.110

15. Gabriel M, Niederer K, Frey $\mathrm{H}$. Wet Chemistry and Peptide Immobilization on Polytetrafluoroethylene for Improved Cell-adhesion. J Vis Exp. 2016;114. http://dx.doi.org/10.379 $1 / 54272$

16. Valente MLC, Shimano MVW, Agnelli JAM, Dos Reis AC. Retention force and deformation of an innovative attachment model for mini-implant-retained overdentures. J Prosthet 
Dent. 2019;121(1):129-134. http://dx.doi.org/10.1016/j. prosdent.2018.04.010

17. de Souza RF, Ribeiro AB, Della Vecchia MP, Costa L, Cunha TR, Reis AC, et al. Mini vs. Standard Implants for Mandibular Overdentures: A Randomized Trial. J Dent Res. 2015; 94(10):1376-84. http://dx.doi.org/10.1177 / 002203451560 1959

18. Goodacre C, Goodacre B. Fixed vs removable complete arch implant prostheses: A literature review of prosthodontic outcomes. Eur J Oral Implantol. 2017;10:13-34.

19. Pisani M, Bedos C, da Silva CHL, Fromentin O, de Albuquerque RF Jr. A Qualitative Study on Patients' Perceptions of Two Types of Attachments for Implant Overdentures. J Oral Implantol. 2017;43(6):476-81. http://dx.doi.org/10.1563 / aaidjoi-D-17-00166

20. Anas El-Wegoud M, Fayyad A, Kaddah A, Nabhan A. Bar versus ball attachments for implant-supported overdentures in complete edentulism: A systematic review. Clin Implant Dent Relat Res. 2018; 20(2):243-50. http://dx.doi.org/10.1111/ cid. 12551

21. Kurbad A. Planning and predictability of clinical outcomes in esthetic rehabilitation. Int J Comput Dent. 2015;18(1):65-84.
22. Cheesborough JE, Liu J, Hsu D, Dumanian GA. Prospective repair of Ventral Hernia Working Group type 3 and 4 abdominal wall defects with condensed polytetrafluoroethylene (MotifMESH) mesh. Am J Surg. 2016;211(1):1-10. http://dx. doi.org/10.1016/j.amjsurg.2015.03.033

23. Neufang A, Espinola-Klein C, Savvidis S, Schmiedt W, Poplawski A, Vahl CF, et al. External polytetrafluoroethylene reinforcement of varicose autologous vein grafts in peripheral bypass surgery produces durable bypass function. J Vasc Surg. 2018;67(6):1778-87. http://dx.doi.org/10.1016 / j.jvs. 2017.09.039

24. Niu G, Sapoznik E, Soker S. Bioengineered blood vessels. Expert Opin Biol Ther. 2014; 14(4):403-10. http://dx.doi.org/10. 1517 / 14712598.2014 .880419

25. de Avila ED, Vergani CE, Mollo Junior FA, Junior MJ, Shi W, Lux R. Effect of titanium and zirconia dental implant abutments on a cultivable polymicrobial saliva community. J Prosthet Dent. 2017; 118(4):481-87. http://dx.doi.org/10.1016 / j. prosdent.2017.01.010

Received on: 6/8/2018 Final version resubmitted on: 22/1/2019 Approved on: 10/2/2019 